\title{
Correction to: A Multi-Perspective Reflection on How Indigenous Knowledge and Related Ideas Can Improve Science Education for Sustainability
}

\author{
Robby Zidny ${ }^{1,2}$. Jesper Sjöström ${ }^{3}$ (D) Ingo Eilks ${ }^{4}$ (D)
}

Accepted: 14 January 2021/ Published online: 13 March 2021

(c) The Author(s) 2021

\section{Correction to: Science \& Education (2020) 29:145-185 \\ https://doi.org/10.1007/s11191-019-00100-x}

The article A Multi-Perspective Reflection on How Indigenous Knowledge and Related Ideas Can Improve Science Education for Sustainability, written by Robby Zidny, Jespe Sjöström and Ingo Eilks, was originally published Online First without Open Access. After publication in volume 29, issue 1, page 145-185 the author decided to opt for Open Choice and to make the article an Open Access publication. Therefore, the copyright of the article has been changed to (C) The Author(s) 2021 and the article is forthwith distributed under the terms of the Creative Commons Attribution 4.0 International License, which permits use, sharing, adaptation, distribution and reproduction in any medium or format, as long as you give appropriate credit to the original author(s) and the source, provide a link to the Creative Commons licence, and indicate if changes were made. The images or other third party material in this article are included in the article's Creative Commons licence, unless indicated otherwise in a credit line to the material. If material is not included in the article's Creative Commons licence and your intended use is not permitted by statutory regulation or exceeds the permitted use, you will need to obtain permission directly from the copyright holder. To view a copy of this licence, visit http://creativecommons.org/licen ses/by/4.0.

The online version of the original article can be found at https://doi.org/10.1007/s11191-019-00100-X

Ingo Eilks

ingo.eilks@uni-bremen.de

1 University of Bremen, Leobener Str. NW2, 28334 Bremen, Germany

2 Department of Chemistry Education, Faculty of Teacher Training and Education, University of Sultan Ageng Tirtayasa, 42117 Serang, Indonesia

3 Department of Science-Mathematics-Society, Malmö University, 205 06, Malmö, Sweden

4 Department of Biology and Chemistry, Institute for Science Education (IDN) - Chemistry Education, University of Bremen, Leobener Str. NW2, 28334 Bremen, Germany 
Open Access This article is licensed under a Creative Commons Attribution 4.0 International License, which permits use, sharing, adaptation, distribution and reproduction in any medium or format, as long as you give appropriate credit to the original author(s) and the source, provide a link to the Creative Commons licence, and indicate if changes were made. The images or other third party material in this article are included in the article's Creative Commons licence, unless indicated otherwise in a credit line to the material. If material is not included in the article's Creative Commons licence and your intended use is not permitted by statutory regulation or exceeds the permitted use, you will need to obtain permission directly from the copyright holder. To view a copy of this licence, visit http://creativecommons.org/licenses/by/4.0

Publisher's note Springer Nature remains neutral with regard to jurisdictional claims in published maps and institutional affiliations. 